HOW

Volume 29, Number 1, pages 105 - 128

https://doi.org/10.19183/how.29.1.653

How

\title{
Speaking in Worlds of Adventure: Tabletop Roleplaying Games within the EFL Classroom
}

\author{
Hablando en Mundos de Aventura: Juegos de Rol de Mesa en el \\ Aula de EFL
}

\author{
Fabio Adrián Torres-Rodríguez ${ }^{1}$ \\ Institución Educativa Santa Teresa de Jesús, Ibagué, Colombia \\ Liliana Martínez-Granada ${ }^{2}$ \\ Institución Educativa Miguel de Cervantes Saavedra, Ibagué, Colombia
}

\begin{abstract}
Fostering spoken communication in a foreign language classroom is not an easy task. With that in mind, this paper explores a proposal to motivate students' L2 oral communication through the practice of narrative games called tabletop roleplaying games adapted as task-based activities. It implied an action research process in which the teacher-researcher with his students reflected and intervened on the identified problematic situation: Lack of oral communication in L2. In that sense, it started with a diagnostic test that showed the current state of verbal communication in L2 in a Colombian rural public school. Next, the teacher-researcher chose to appeal to the gamification of the classroom along with the adoption of a task-based framework to activity design aiming to improve students' motivation to take the risk of communicating in L2. The teacher-researcher applied sets of activities that progressed from traditional role-play to a tabletop roleplaying game. In accordance, video
\end{abstract}

He holds a Bachelor in English from the Universidad Del Tolima and he is a candidate to Master in English Didactics from the Universidad del Tolima. He is a teacher at the Institución Educativa Santa Teresa de Jesus in Ibague. He has 8 years of experience working in rural and urban contexts.

fatorresr@ut.edu.co

ORCID ID: https://orcid.org/0000-0002-9695-8859

She holds a master in English Teaching. She is a teacher at the Institución Educativa Miguel de Cervantes Saavedra, Ibagué, Tolima. She is also a part time teacher at the University of Tolima and researcher of the Research Group of Languages Didactics, University of Tolima.

lmartinezg@ut.edu.co

ORCID ID: https://orcid.org/0000-0002-2409-6321

Received: May 2nd, 2021. Accepted: October 13th, 2021.

This article is licensed under a Creative Commons Attribution-Non-Commercial-No-Derivatives 4.0 International License. License Deed can be consulted at https://creativecommons.org/licenses/by-nc-nd/4.0. 
Fabio Adrián Torres-Rodríguez,

Liliana Martínez-Granada

recordings, narratives, artifacts collections, and semi-structured interviews were essential to collect data. Afterward, the teacher-researcher analyzed the data with an emic approach to identify patterns in the information that uncovered the categories and subcategories of information. Consequently, the teacher-researcher concluded that the students feel better motivated using L2 if the learning environment offers opportunities for social interaction, collaborative work, and scaffolding in taskbased exercises embedded in a fictional world game.

Keywords: gamification, motivation, oral communication, tabletop roleplaying games, task-based activities

\section{Resumen}

Fomentar la comunicación oral en un aula de lenguas extranjeras no es tarea fácil. Con eso en mente, este artículo explora una propuesta para motivar la comunicación oral en L2 por medio de la práctica de juegos narrativos llamados juegos de rol de mesa adaptados como actividades basadas en tareas. Esto implicó un proceso de investigación-acción en el que el docente-investigador con sus alumnos reflexionó e intervino sobre la situación problemática identificada: Falta de comunicación oral en L2. En ese sentido, se inició con una prueba diagnóstica que mostró el estado de la comunicación oral en L2 en una escuela oficial rural colombiana. A continuación, el docente-investigador optó por apelar a la ludificación del aula junto con la adopción de un marco basado en tareas con el objetivo de mejorar la motivación de los estudiantes a tomar el riesgo de comunicarse en L2. El docente-investigador implementó conjuntos de actividades que progresaron de juegos de roles tradicionales a juegos de rol de mesa en el aula. De acuerdo con ello, la grabación de video, narrativas, la recolección de artefactos y entrevistas semi-estructuradas fueron esenciales para recopilar datos. Posteriormente, el docente-investigador analizó los datos con un enfoque émico para identificar patrones en la información que develó las categorías y subcategorías de información. En consecuencia, el docente-investigador concluyó que los estudiantes se sienten mejor motivados para usar L2 si el entorno de aprendizaje ofrece oportunidades para la interacción social, el trabajo colaborativo y el andamiaje en ejercicios basados en tareas en el marco de un juego de mundo ficticio.

Palabras clave: actividades basadas en tareas, comunicación oral, ludificación, motivación, juegos de rol de mesa

\section{Introduction}

English over time has become one of the most used languages around the world thanks to its political and cultural power and evident influence in technology, scientific advancements, communication, and education (Christiansen, 2015; Martin-Rubió, 2018). As a consequence, the importance of English as an international language has made it a necessary subject in all Colombian schools (MEN, 2016). Nevertheless, in many EFL classrooms around the world, it has been hard to help students achieve successful/proficient oral communication in L2 (Coşkun, 2016; Rivera, 2010; Vaca \& Gómez, 2017; Vargas, 2015). 
Therefore, teachers usually look to adopt and implement strategies that facilitate the speaking process and raise the students' pleasure of talking regarding their L2 proficiency level, needs, expectations, and learning styles. In that vein, I, as a teacher-researcher, proposed the use of tabletop roleplaying game mechanics (Grouling, 2010; Reinhold, 2018) to present engaging and fun task-based activities focused on oral communication in an L2 (Richards \& Rodgers, 2001; Nunan, 2004; Ellis, 2018).

With than in mind, I carried out this action research proposal in a rural school setting where I was an English as a foreign language teacher. The school was a public, rural institution in Icononzo, a town in the department of Tolima, Colombia, where students showed great difficulties expressing their ideas orally and spontaneously in English, as the target L2.

In respect to that matter, this research question emerged: How does the application of tabletop roleplaying games (TRPGs), used as task-based activities, give evidence concerning the development of speaking English as a foreign language process?

Accordingly, this research question proposal followed these research objectives: First, to describe how to use TRPGs as task-based activities. Second, to evidence how TRPGs could affect seventh graders' EFL speaking development if used as gamified task-based activities. Finally, to explore TRPGs as an alternative to impact the EFL classroom learning environment and motivation.

Eventually, this action research study could be helpful for those teachers who look for strategies to raise their students' motivation to communicate in L2 intervening in their EFL classroom environment through gamification. As such, a study about the use of TRPGs in an EFL classroom could identify possible alternatives to face barriers towards oral activities. Thus, teachers might find the study useful to modify interactive exercises in classrooms different from TRPGs that have similarities; for example, sketches, performances, monologues, role-plays, and simulations (Scrivener, 2005).

\section{Theoretical Framework}

\section{Gamification}

Nowadays, the requirement/necessity of motivating students has led to a search for strategies that involve games as a way of making students feel better at learning. Cassie (2016) points out that many professionals have looked for answers in game-based education, using games designed for curricula and lesson integration. However, others are not focused on specific games but in-game mechanics to modify the classroom environment, a strategy better known as "gamification" (Cassie 2016; Crocco, 2016; Woods 2016). Montoya and Uribe (2016) explain that gamification implies adopting game mechanics to improve students' 
motivation to work on a task. Hence, the focus of the exercise becomes the learning objective rather than the recreational nature of a game. It is necessary to keep it in mind because teachers must plan gamified activities thinking first of the pedagogical value of such exercise, setting a clear learning objective, but without forgetting the enjoyment of the task.

Thus, a gamified classroom looks for motivating students through game mechanics like achievement systems, experience points, and skill trees (Cassie, 2016). For example, Crocco (2016) states that gamification can be of great use in the classroom if roleplaying games' mechanics are adapted. For example, he explains that grades can be taken as experience points and that record sheets are good ways of keeping track of progress (p. 285).

Perdomo and Rojas (2019) also reflected on gamification as a pedagogical tool in a Colombian context. Accordingly, they found it positive to offer students the opportunity of getting immediate feedback through the implementation of gamified activities where students can earn badges, tokens, and levels that indicate their progress. However, they highlight that it is necessary to equilibrate both extrinsic and intrinsic motivation proposing satisfactory and meaningful "tasks" for the student. While experience points, badges, and levels give good extrinsic motivation, it is essential to foster feelings of self-realization and achievement to strengthen students' intrinsic motivation.

Finally, to comprehend why gamification works, Woods (2016) states that gamification requires the understanding that learning is always happening with any activity, and in that case, it is much better if that activity is fun and engaging. Hence, the idea behind gamification is that what makes players play is not only aimed at games but can be adopted in different contexts to promote learning by participating in communities of practice and fun (Woods, 2016).

\section{Tabletop Roleplaying Games - TRPGs}

Gaming mechanics, context, and challenges are elements common to TRPGs. These are leisure activities developed around 1970 as a variant of board wargames but focused on storytelling (Rocha, 2018; Grouling, 2010; Reinhold, 2018). Likewise, they are cooperative games with clear rules and goals to exert control over the narrative exercise wherein there are 108 no losers (Ferreira \& Carvalho, 2013, p. 81).

In that sense, TRPGs are a form of storytelling activity that makes use of the idea of taking roles similar to the 'role-play' classroom activity. Therefore, TRPGs offer learners the opportunity to adopt fictional roles in non-threatening environments (Gower et al., 2005; Scrivener, 2005; Mackey \& Gass, 2005). Moreover, these games have the particularity that the players' interactions are unscripted and many situations in the game can change due to players decisions or bad luck, consequently, affecting the story being told. 
To summarize, these games have the following characteristics: First, they are collaborative tabletop storytelling games, contrary to competitive games. There are two types of players: character players, who assume the roles of main characters, and the game master (or storyteller), who adopts the rest of the secondary characters and antagonists in the story. Second, people can find TRPGs comercially in sets of books that give details and images of landscapes, people, politics, ecology, artifacts, and creatures about the universe proposed for the game. Third, they offer systems to determine the possibility of succeeding or failing narrative actions, usually through statistics, simple mathematics calculi, and polyhedral dice. Fourth, they stem heavily from pop culture tropes (Mackay, 2001; Crocco, 2016).

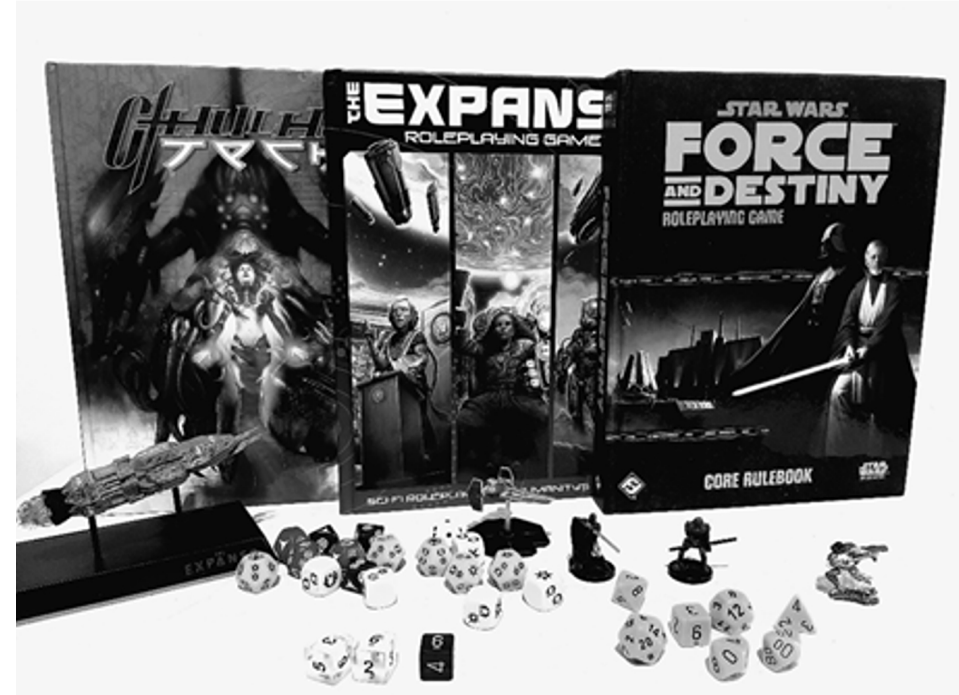

Figure 1. Examples of Tabletop Roleplaying Games

Note. Cthulhutech (n.d.) is a registered trademark of Wildfire Publishing; The Expanse Roleplaying game (2019) is a registered trademark of Green Ronin Publishing; and Star

Wars Force and Destiny Roleplaying Game (n.d.) is a registered trademark of Fantasy

Flight Games. Source: The photograph is my own elaboration.

In that regard, a number of authors have come to reflecting on TRPGs as a strategy for the EFL classroom. For instance, Woods (2016) presented an essay about TRPGs as a viable methodology for instruction in classrooms thanks to the possibility of creating a learning environment that fosters agency and emotional engagement in the process. In that vein, he highlights that TRPGs directly affect students' socialization skills and, as such, it strengthens language production. Moreover, Rocha (2018) carried out a project that gives evidence of 
Fabio Adrián Torres-Rodríguez,

Liliana Martínez-Granada

TRPGs' effectiveness in answering students' lack of interest, a common problem in EFL classrooms. Also, he points out that TRPGs have an innate task-based nature that teachers could make the most of. Poovey (2014) presented in the Wake Forest University Magazine the experience of a Latin language teacher that adapted TRPG mechanics to create fictional situations wherein students could practice Latin. Another research work in a Brazilian medical program (Ferreira \& Carvalho, 2013), although not an EFL study, showed that TRPG activities improve students' social skills and scaffolding, offering conditions where collaborative work becomes desirable and necessary. The authors highlight that TRPGs present opportunities for peer instruction deemed meaningful for academic progress.

\section{Task-Based Language Teaching and Learning (TBLT)}

Richard and Rogers (2001) summarize task-based language learning and teaching as tasks that involve real communication in which language is used for carrying out meaningful activities that promote learning (p. 223). Hence, social interaction is necessary, and in that sense, TBLT suggests roles for the classroom participants: as learners who take the role of group participants and communicative partners working in pairs or small groups. Furthermore, they become monitors of their language learning process and need to be risktakers and innovators to answer to the communicative challenges that teachers present them. There are also teacher roles as selectors and sequencers of tasks; teachers need to select and organize tasks in a coherent way regarding students' needs, interests, and language skill levels (Richards \& Rodgers, 2001).

Nunan (2004) defines tasks as "a piece of classwork that encourages students to manipulate, comprehend and interact with the target language focusing on meaning rather than form" (p. 4). Nunan (2004) divides "task" into two types: "Rehearsal tasks" and "activation tasks" (pp. 19-22). Rehearsal tasks are activities in which students practice functions and notions that reflect what students will need in the real world. On the other hand, activation tasks are activities that look for activating emerging language skills. Although the practice of functions and notions is a good start, teachers and learners should move from a reproductive model of language use to one of language production, applying their emerging language skills, and developing sociolinguistic, and paralinguistic

110 competencies in real and innovative contexts (Nunan, 2004). For example, Nunan (2004) presents an activation task in which students find themselves on a sinking ship. The participants must decide what items are the most necessary ones to take, survive, and escape (pp. 20-21).

Furthermore, Ellis (2018) explains that a task is a "work-plan" to use language in a pragmatic form to achieve a communicative outcome and convey the appropriate content. As such, a task presents the context whereby a learner can use L2 meaningfully. As a work- 
plan, tasks have the following criteria: first, focus on meaning; second, learners must fill a gap when the task is over; third, learners must rely on their linguistic resources and communication strategies; and fourth, tasks should/must have a clear communicative goal. Therefore, evaluation takes into account what students achieve to communicate (p. 16). In summary, as Córdoba (2016) described in a Colombian study, TBLT is a methodology in which a teacher challenges students with activities that they could find in their daily life and that require the application of competencies and language skills. Therefore, language becomes a means to execute a plan. Hence, this methodology presents several advantages that Rodríguez and Rodríguez (2010) highlighted in their study in a Colombian university. First, they concluded that task-based learning encourages autonomy. Second, past experiences and previous knowledge support learning. Third, there are several types of "tasks" (as based on daily-life activities), which make classes more varied. Finally, language becomes a means to reach a goal rather than being the goal itself.

\section{Oral Communication}

Monsalve and Correal (2006) interpreted oral communication as a process in which input and output of spoken language are constantly generated with the aim of negotiating meaning. Thus, oral communication is any form of interaction that makes use of words in spoken form and is received through listening both face to-face or through technological devices (Juneja, 2019). Oral communication can be formal or informal. Examples of formal oral communication are presentations in academic or business contexts, speeches in ceremonies, and classroom reading activities. Examples of informal oral communication are face-to-face conversations, cellphone conversations, discussions in meetings, and competitive and collaborative games (Swarthout, 2019).

However, speaking in a foreign language can be a difficult skill to develop in EFL classrooms, especially in state institutions where methodologies and resources are not the best. Several studies have touched upon this problem. For instance, a Turkish study described the problem as the "I can understand English, but I can't speak it" syndrome (Coşkun, 2016, p. 4); this author concluded that traditional grammar-focused foreign language teaching is not useful to the encouragement of speaking. Second, a Colombian study found that it is imperative to check the way students and teachers generate oral communicative interaction among themselves, it being especially imperative to check teaching methodologies (Rivera, 2010). Third, another Colombian study dealt with students' lack of motivation to produce oral communication due to grammar and teacher-centered practices (Vaca \& Gomez, 2017). Finally, a Costa Rican study showed how the verbal skill is affected by the lack of motivation, learning environment, and interference from the mother tongue due to the lack of a context that demands the exclusive use of English (Vargas, 2015). 
Fabio Adrián Torres-Rodríguez,

Liliana Martínez-Granada

\section{Learning Environment and Motivation}

It is essential to encourage students to learn from the process of interacting in the classroom on a student-student and student-teacher basis, conveying meaning from oral or written messages that are meaningful and interesting for them (Rivera, 2010). Therefore, the teacher must transform the classroom into a place where confidence leads to active verbal participation in social exchanges. Consequently, activity design should improve motivation and foster an environment wherein verbal communication can be spontaneous and enjoyable. Accordingly, teachers should regard students' individualities to let them apply their learning styles and offer them challenges that can be meaningful for them. These challenges or tasks become significant if they allow students to feel part of something, a group. When students themselves feel part of a group, they invest more in their ability to communicate and will see opportunities of expressing their talents to collaborate in their group. In that regard, to interact and express themselves, students will invest more in their EFL learning process and, thanks to social cohesion and group support, they will improve their self-confidence (Peirce, 1995). In that way, students will identify the target language as necessary in order to be part of a social group, which fosters intrinsic motivation.

Intrinsic identified motivation is described in Vansteenkiste, Lens, and Deci's (2010) self-determination theory. This theory places a strong emphasis on the necessity of fostering self-regulated motivation in students via offering them activities that they can identify with as beneficial and enjoyable (Vansteenkiste, et al., 2010, p. 21). Therefore, it is necessary to appeal to teaching practices that regard students' individualities in contingent interaction activities (Rivera, 2010) and interconnected learning processes where everyone learns from each other, facilitating scaffolding (Garcia, 2016).

\section{Methodology}

The present study seeks to understand a problematic situation in an EFL classroom (student motivation and speaking production). With that in mind, an action-research methodology was applied, that is, a research model that seeks to foster teacher and student development in pedagogical practices (Mackey \& Gass, 2005). Action research invites

112 teachers, along with students, to reflect on their practices and try to identify a problem and think of a way to figure out the possible solutions to it (Burns, 2009).

\section{Context}

This study was carried out in a government, rural educative institution in the town of Icononzo, in the department of Tolima, Colombia. It deals with school levels from first to eleventh grade with an average socio-economic stratum of one or two (low). There is an 
average of twenty-five to thirty students per classroom. Additionally, there is not an English language teacher at elementary school (first to fifth grades); for middle and high school (sixth to eleventh grades), there is only one English language teacher in charge of all the courses. Students at the school showed great difficulties in expressing their ideas orally in the foreign language classroom. Moreover, contextual hindrances made the production of spoken communication harder, namely: the lack of resources at the school, an inadequate learning environment, and the lack of an English language teacher for the elementary school. The participants in this study were 18 seventh-grade students, with ages ranging from 11 to 13 years old, and their sole English language teacher. Time-allocation for English classes was of three hours a week. There were no appropriate spaces to give and take language lessons (classroom exposed to constant street noise), but there was access to video beam.

\section{Research Stages}

Action research, as proposed by Nunan (1992), follows a series of stages: initiation, preliminary investigation, hypothesis, intervention, and evaluation. The process starts with the identification of a problematic situation during my teaching practices: in this case, the lack of students' oral production in English as the L2. In preliminary observations, I, being the teacher-researcher, evaluated the participating students' level of oral production at the beginning of the study using the CEFR Grid for Speaking Test designed by the Association of Language Testers in Europe (2014) as a reference. I made use of a rubric based on a design by the Alkor School that follows the KET placement test parameters (Colegio Alkor, 2016). From the results, an initial hypothesis was formed: Students are good at learning and using prefabricated patterns but are weak at spontaneous oral communication.

The intervention stage implied the application of four activities to foster oral communication in English as the L2 as seen in Table 1.

The first and second intervention activities were pilots to start preparing the participating students for more complex TRPGs. The first activity was a board role-play game named "The Touristic Town, Icononzo" that was projected via video beam. I organized the class into four groups of four or five students (the process repeated in each one of the interventions). To reach the end square, they had to interact with fictional situations and characters that were impersonated by me in most of the squares. The second intervention activity was closer to a traditional role-play, also to prepare the students for more complex TRPGs. In this case, the fictional context simulated the students' town. The students were given other identities in the role-play activity named "Tourist guide in Icononzo (role-play)." I gave the students a general description of the situation and set the task for them: to find a place to have lunch with the tourist. These activities took one week and three sessions. 
Table 1. Activity interventions.

\begin{tabular}{|c|c|c|c|}
\hline Activity name & Objectives & Materials & Procedures \\
\hline $\begin{array}{l}\text { The Touristic } \\
\text { town, Icononzo }\end{array}$ & $\begin{array}{l}\text { Preparation to } \\
\text { role-play. }\end{array}$ & $\begin{array}{l}\text { Video projection of } \\
\text { board game, dice. }\end{array}$ & $\begin{array}{l}\text { Group conformation. } \\
\text { Explanation of game rules. } \\
\text { Solution of } \\
\text { communication challenges } \\
\text { in each square to reach } \\
\text { the game's end. }\end{array}$ \\
\hline $\begin{array}{l}\text { Tourist guide } \\
\text { in Icononzo } \\
\text { (role-play) }\end{array}$ & $\begin{array}{l}\text { Practice of fictional } \\
\text { roles in simulated } \\
\text { context. } \\
\text { Preparation } \\
\text { for TRPGs. }\end{array}$ & $\begin{array}{l}\text { Video projection of } \\
\text { fictional characters } \\
\text { and situations. }\end{array}$ & $\begin{array}{l}\text { Presentation of a task } \\
\text { in a simulated context } \\
\text { that requires interaction } \\
\text { with fictional characters } \\
\text { to find a resolution. }\end{array}$ \\
\hline Hunting a monster & $\begin{array}{l}\text { TRPG mechanics } \\
\text { implementation. } \\
\text { Roleplaying characters } \\
\text { in fantasy context. } \\
\text { Resolution of tasks. }\end{array}$ & $\begin{array}{l}\text { Video projection of } \\
\text { fictional characters, } \\
\text { scenarios and } \\
\text { context. Dice. }\end{array}$ & $\begin{array}{l}\text { Group conformation. } \\
\text { Game rules explanation. } \\
\text { Storytelling and } \\
\text { presentation of a fictional } \\
\text { situation that requires } \\
\text { solving a series of tasks } \\
\text { to reach resolution. }\end{array}$ \\
\hline $\begin{array}{l}\text { Finding the } \\
\text { Castellan's son }\end{array}$ & $\begin{array}{l}\text { TRPG mechanics } \\
\text { implementation. } \\
\text { Roleplaying characters } \\
\text { in fantasy context. } \\
\text { Resolution of a } \\
\text { series of tasks. }\end{array}$ & $\begin{array}{l}\text { Video projection of } \\
\text { fictional characters, } \\
\text { scenarios and } \\
\text { context. Dice. }\end{array}$ & $\begin{array}{l}\text { Group conformation. } \\
\text { Game rules explanation. } \\
\text { Storytelling and } \\
\text { presentation of a fictional } \\
\text { situation that requires } \\
\text { solving a series of tasks } \\
\text { to reach a resolution. } \\
\end{array}$ \\
\hline
\end{tabular}

The third and fourth intervention activities were full-fledged TRPGs. The students were already familiarized with the concept of taking on fictional roles. Therefore, for these activities, I proposed as tasks to hunt a fictional monster that was lurking in a forest near a town and rescue a fictional character lost in that forest. Again, the students were organized in 114 groups, each group assigned with a fictional character with a general description of skills, as well as physical and mental attributes. They were explained the game mechanics of skill score plus die roll to determine failure or success of an action. These activities took two weeks and six sessions to be resolved.

The evaluation stage implied data collection and analysis. This study obtained data from three sources: video recordings observations, artifacts, and audio-recorded, semi-structured interviews. Being an emic approach to research, the data in this action research suggested 
the basic categories for organizing and analyzing the collected information (Mackey \& Gass, 2005).

\section{Data Collection Procedures}

The goal of data collection techniques was to gather information in a naturalistic way while retaining the consistency of the information (Mackey \& Gass, 2005). The following techniques were the most suitable ways to collect data answering to the objectives of this study:

- Diagnostic test. This test worked as the preliminary investigative stage. During this test, the students' L2 speaking performance was analyzed. The test had as the main topic "family and friends". The required grammar was the present simple tense. 18 seventh-grade students were invited to take the test freely with three days of anticipation.

- Class observation video recording: It implied first-hand observation of game exercises backed up by video-recordings and journal narratives. The games took place for three weeks, each game taking from one to three sessions with 18 seventh-grade students.

- Audio recorded semi-structured interviews: these documented the participating students' opinions and possible suggestions about TRPGs, which collected pieces of evidence of satisfaction level and possible suggestions for improvement. I prepared three basic questions: (1) What is your opinion about the activity? (2) How much do you think you learnt or progressed in English? (3) How did you feel at the moment of speaking in English? I held interviews with four groups of four and five of the participating students. Each interview took between four and five minutes.

- Students' artifacts: I kept samples of the students' production. The artifacts offered tangible pieces of evidence of changes in the students' EFL learning process. These artifacts were samples of language production in the students' notebooks. These samples required digital scanning of notebook pages.

\section{Data Analysis}

This study started the data collection process with a diagnostic test applied to 18 students of seventh grade at the rural school. Their English language proficiency level was A1, according to the competences described in the CERF (ALTE CEFR Special Interest Group (SIG), 2016). The diagnostic test implied an inductive approach to coding and categorizing this instrument. It was analyzed by comparing the students' speaking performance with a rubric with ranging criteria on grammar, pronunciation, vocabulary, and comprehension with scale performance based on the marking ranges in the school's SIEE (Institutional system of students' evaluation). The scales were as presented in Table 2 below. 
Table 2. Range Scales of Performance in the Diagnostic Test.

\begin{tabular}{|l|c|}
\hline \multicolumn{1}{|c|}{ Performance } & Range \\
\hline Excellent & $9,6-10$ \\
\hline Good & $8-9,5$ \\
\hline Satisfactory & $6-7,9$ \\
\hline Low & $1-5,9$ \\
\hline
\end{tabular}

I organized the data sets of numerical values into the subcategories of excellent, good, satisfactory, and low under the category performance according to the rubric scales. Thus, I used simple mathematical calculi to determine their percentage in the total of answers. In this way, I got information to get a hypothesis, namely: Students are good at learning and using prefabricated patterns but are weak at spontaneous oral communication.

Once I had a diagnosis about the participating students' speaking performance in English as the L2, observation and analysis of information were necessary from inside the research context. From this point on, this study followed an emic approach to research. Thus, the data in this action research suggested the basic categories for organizing and analyzing the collected information (See Tables 3, 4, and 5 for details). Data analysis followed a procedure inspired by Burns' (2009) suggestions to analyze and synthesize qualitative data with her "categorizing" and "talk analysis" procedures. "Analyzing talk" entailed the analysis of spoken interaction following the next steps; first, information gathering: data collection in the form of video recordings and semi-structured interviews. Second, general characterization: It means identifying the kind of interaction. Third, identification of grossly apparent features: implies identifying the participant's roles and actions. Fourth, focus on structural elements: interpretation of participants' actions and decisions. "Categorizing" implied the coding of patterns in the video recordings and semi-structured interviews descriptions and artifacts as the third source of data. Hence, it led to the identification of theme frequencies that gave numerical references that facilitated the data analysis and categories classification.

\section{Findings}

The first set of data to be analyzed was the diagnostic test. This diagnostic test was applied to the 18 seventh-grade participants before the interventions. I applied the diagnostic test in the form of an interview about family members and their professions, placing emphasis on present simple grammar and the use of can and can't. The graphics in Figure 2 below show results per category of performance in grammar, pronunciation, vocabulary and listening comprehension. 

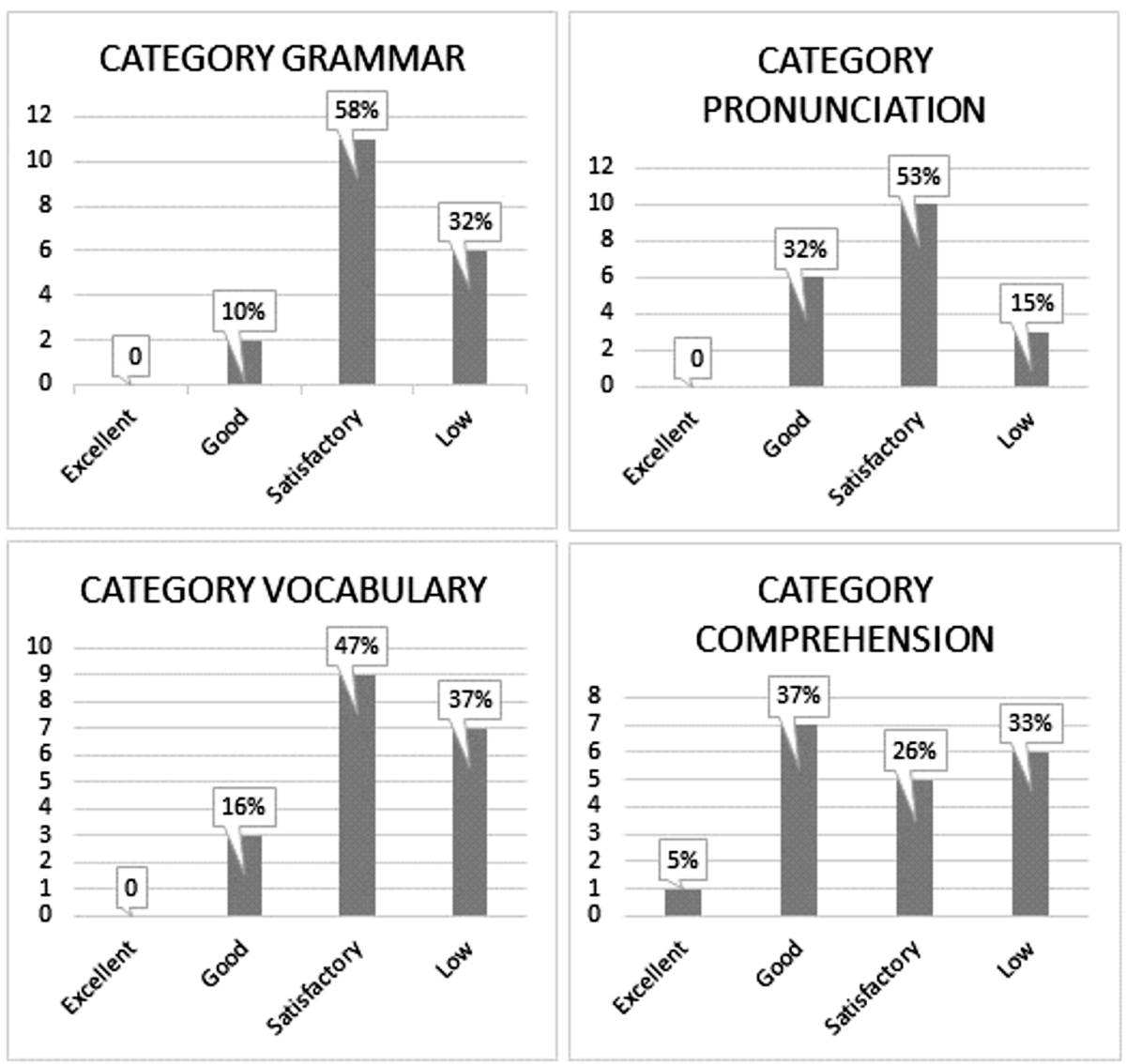

Figure 2. Percentage of Results per Category in the Diagnostic Test.

In general, the diagnostic test showed a tendency toward a satisfactory level of performance on oral activities prepared in advance; in this case, an interview about family members and their professions. However, what happened with the $32 \%$ of low results in grammar? The $15 \%$ low results in pronunciation? The $37 \%$ of low results in vocabulary? And the $32 \%$ of low results in listening comprehension? I decided to inquire about these from the participating students that got low results. They declared that they did not learn phrases or dialogues by heart. It coincided with my observation of heavy use of prefabricated patterns (Dörnyei, 1995) on the part of the students that achieved positive results. Thus, I came up with a hypothesis: Students are good at learning and using prefabricated patterns but are weak at spontaneous oral communication. 
Fabio Adrián Torres-Rodríguez,

Liliana Martínez-Granada

After the intervention stage, the first data source consisted of 198 minutes of video recordings of six class sessions. I adopted a chart to keep a journal of narratives about what happened in the videos. I labeled each chart with the name of the intervention and a short description: Tourists in Icononzo (Intervention one, board game, role-play, 20 minutes); Tourist guides in Icononzo (Intervention two, role-play, 35 minutes); "hunting a monster" (Intervention three, TRPG, 35 minutes); "Finding the Castellan's son" (Intervention four, three classes, TRPG, 108 minutes). Next, I looked for identifying critical events in the labeled charts to figure out grossly apparent features, such as reception, performance, and possible shortcomings. Then, I looked for identifying and codifying the structural elements that would become the basis for the general feature categories; for example: to explain the reception, seeing the synergic relationship among enjoyment, teamwork, teacher's monitoring, and learning styles is necessary. Below, Table 3 shows the codes of this analysis and their frequency; in the last column, the category that better suits them appears.

Table 3. Codes and Categories from Video Recordings

\begin{tabular}{|c|c|c|c|c|c|}
\hline $\begin{array}{l}\text { Code Entry } \\
\text { Description }\end{array}$ & $\begin{array}{c}\text { \# Entries } \\
\text { Intervention } 1\end{array}$ & $\begin{array}{c}\text { \# Entries } \\
\text { Intervention } \\
2\end{array}$ & $\begin{array}{c}\text { \# Entries } \\
\text { Intervention } \\
3\end{array}$ & $\begin{array}{c}\text { \# Entries } \\
\text { Intervention } \\
4\end{array}$ & Categories \\
\hline $\begin{array}{l}\text { Enjoyment of } \\
\text { gamified activity }\end{array}$ & 5 & 6 & 7 & 7 & Reception \\
\hline $\begin{array}{l}\text { Stimuli to } \\
\text { learning styles }\end{array}$ & 4 & 4 & 3 & 4 & \\
\hline $\begin{array}{l}\text { Teachers' } \\
\text { monitoring }\end{array}$ & 1 & 5 & 0 & 5 & \\
\hline Teamwork & 5 & 3 & 3 & 6 & \\
\hline $\begin{array}{l}\text { Spontaneity of } \\
\text { language use }\end{array}$ & 8 & 7 & 8 & 10 & Performance \\
\hline $\begin{array}{l}\text { Emerging } \\
\text { skill activation } \\
\text { (language, } \\
\text { sociolinguistic, } \\
\text { and paralinguistic } \\
\text { competencies) }\end{array}$ & 5 & 4 & 3 & 5 & \\
\hline Group size & 0 & 0 & 0 & 2 & $\begin{array}{l}\text { Short- } \\
\text { comings }\end{array}$ \\
\hline Discipline issues & 0 & 0 & 0 & 2 & \\
\hline Total Entries & & 121 & & & \\
\hline
\end{tabular}


To facilitate the comparison of code frequencies in the interventions, I used a Microsoft Excel worksheet to make a graphic that would show the frequencies. Figure 3 below displays that graphic.



Figure 3. Comparison of Code Frequency in Video Recording Narratives

According to the frequencies, the participating students showed a good level of reception of/as regards the activities agreeing with the emerging code "enjoyment of gamified activity", which synergized with the codes "stimuli to learning styles", "teamwork", and "teachers monitoring" as presented in Figure 3. Regarding the code "enjoyment of gamified activity", I saw a positive evolution in the frequency of entries from role-plays to TRPGs. Also, I observed that the code "stimuli to the students' learning styles" emerged with a small difference in favor of role-play activities. Furthermore, teachers' monitoring contributed to the reception of the activity. The students felt they could count on my help at any moment. To exemplify how students enjoyed the activities, I share an example of an entry in the narrative journal: "Students celebrate the success of rescuing one of the characters. Again, it is clear that students tend to enjoy the story twists that happen thanks to the game mechanics of a tabletop roleplaying game." In several cases, the students' enjoyment had to do with the unscripted nature of TRPGs. In other words, TRPGs do not have a set script, and events can change dramatically according to participants' decisions. Hence, the gamified factor and uncertainty of results were part of the game appeal of TRPGs.

Additionally, the students' performance also showed a positive evolution in all the interventions. In effect, the spontaneity of language use was the code with the most frequencies having more entries in the TRPGs narratives. Under the category of performance, 
the "emerging skills" code appeared with higher incidence during the interventions with emphasis on role-play activities. This code contemplated the development of sociolinguistic and paralinguistic competencies during the interventions, which implied that students actively engaged in communication events taking into consideration the correct approximation to the interlocutor and interpretation of gestures and body language. Additionally, I saw teamwork as a key element that showed a positive evolution. Next, I cite one example of an entry in the narrative journal about spontaneity, sociolinguistic competence, and teamwork: "Students exchange ideas among them [selves], proposing ways to rescue the friend that fell into the river, they discuss it in Spanish and star looking the way of communicating it in English, this is a clear show of collaborative work."

However, I detected shortcomings at the moment of working on the interventions. In particular, the fourth intervention, being the longest one, showed the problems that could appear; misbehavior and the difficulty of working with large groups. I cite one example from the narratives: "...disciplinary issues can arise, in this case, was not a big problem, but it was evident that students tend to divert themselves easily due to the close interaction in the groups."

For the artifacts, I deemed it necessary to keep written texts from the students due to the students' procedure of designing their discourses in written form before they shared them orally. Once I got the students' samples of language production, I organized them into "interventions". I read each set of samples looking for generalities; the creation of meaningful texts to share orally was evident although they presented English language accuracy problems. Hence, I thought of the general category that I called performance. In that sense, I searched for structural elements that would give sense to my general category. My aim was to find pieces of evidence of text production that was meaningful due to the context and minimal grammatical elements. I called these fragments of text production "thoughts": ideas, proposals, reactions, questions, and opinions. As a result, three codes emerged from the data: thoughts with some inaccuracy, thoughts with basic accuracy (basic clauses), and incomprehensible texts. In table 4 below, I organized the codes and their different numbers of samples per intervention.

Table 4. Codes and Categories from Artifacts

\begin{tabular}{|l|c|c|c|c|c|}
\hline \multicolumn{1}{c|}{$\begin{array}{c}\text { Code Entry } \\
\text { Description }\end{array}$} & $\begin{array}{c}\text { \# Samples } \\
\text { Intervention } \\
\mathbf{1}\end{array}$ & $\begin{array}{c}\text { \# Samples } \\
\text { Intervention } \\
\mathbf{2}\end{array}$ & $\begin{array}{c}\text { \# Samples } \\
\text { Intervention } \\
\mathbf{3}\end{array}$ & $\begin{array}{c}\text { \# Samples } \\
\text { Intervention } \\
\mathbf{4}\end{array}$ & Category \\
\hline $\begin{array}{l}\text { Thoughts with } \\
\text { some inaccuracy }\end{array}$ & 8 & 7 & 11 & 22 & Performance \\
\hline $\begin{array}{l}\text { Thoughts with } \\
\text { basic accuracy }\end{array}$ & 0 & 1 & 1 & 3 & \\
\hline $\begin{array}{l}\text { Incomprehensible } \\
\text { texts }\end{array}$ & 0 & 0 & 1 & 5 & \\
\hline Total Samples & $\mathbf{5 9}$ & & & & \\
\hline
\end{tabular}


Then, I facilitate the comparison among those interventions by entering the information in a Microsoft Excel worksheet to make a graphic. Figure 4 below shows that graphic.

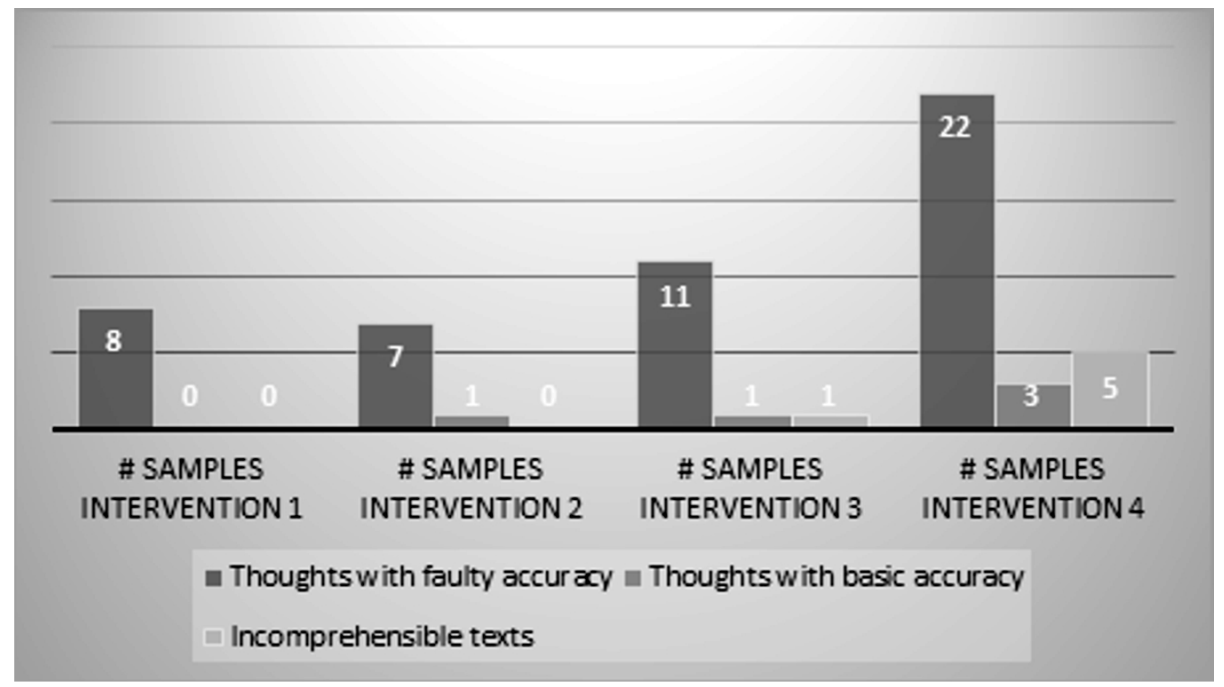

Figure 4. Code Frequency in the Artifacts

In light of the data, I saw a progressive increase in the number of text samples with comprehensible meaning, achieving the highest number in the fourth intervention, which had/allowed more time to be developed. However, intervention three had the same time as intervention two, and yet, there were more samples of "thoughts" in the third intervention. Intervention four presented twice as many samples in twice the amount of time as had the third intervention. One important thing about the time spent in the fourth intervention was the easiness/its facility and possibility of continuity. While an isolated role-play lasted for a class period, a TRPG could last for several lessons appealing to the shared narrative experience (Grouling, 2010). Below, I share three examples of the students' language production.

The third source of data to be analyzed was the students' voices regarding their opinions about the application of TRPGs as a class activity. Three questions led/guided the answers: 'What's your opinion about the TRPG activity?', 'How much do you think you learned or progressed in English?', and 'How did you feel at the moment of speaking in English?' The answers fell into three categories: reception, progress sensation, and suggestions for implementation. 


\section{I to them to recomend the cool acuarios. is (1) very good

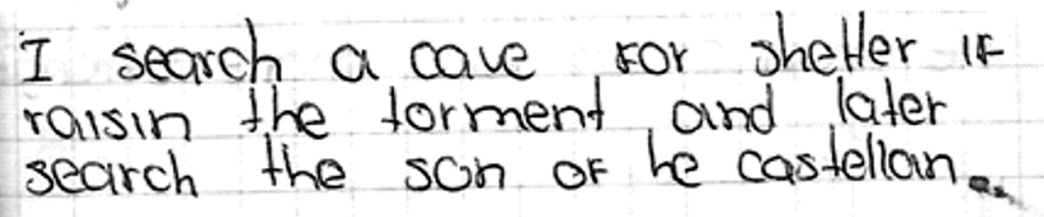

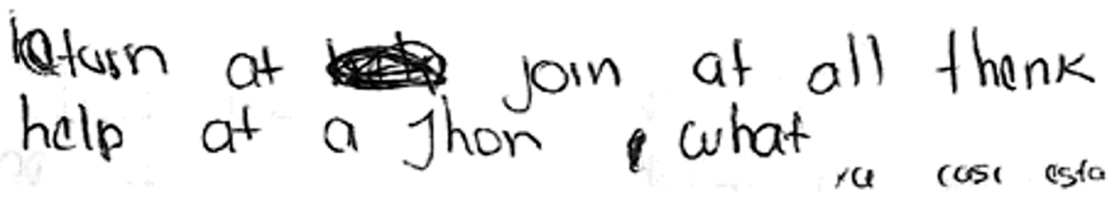

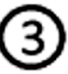

Figure 5. Examples of Students' Language Production

Note. Example one: thought with faulty accuracy.

Example two: thought with basic accuracy. Example three: incomprehensible text.

The first category was the general reception of the activity, and quickly, once I read the different answers, the word that arose was enjoyment. Hence, the students stated that thanks to more enjoyable class activities, they were able to learn better. Thus, enjoyment was codified and became part of the category reception.

The second category was progress sensation. Learning and improving language knowledge were the most common words used by the students. Besides, how the students highlighted teamwork as a critical element for them to achieve confidence was significant. In that sense, I identified the following recurrences: learning awareness, confidence, and teamwork. These recurrences became the codes for the category progress sensation.

The third category of information was students' suggestions for implementation: Many students declared that they felt comfortable with the activities. Nevertheless, a number of answers in the interviews that suggested more variety and maybe more realistic fictional settings were considered. The identified recurrences were: feeling comfortable with the activity and desire of variety. A summary of the emerging codes and their categories is presented in Table 5 below. On the table, the number of recurrences for each code and the category that these gave me as a result can be seen. 
Table 5. Recurrences, Codes and Categories in the Semi-Structured Interviews.

\begin{tabular}{|l|c|l|}
\hline \multicolumn{1}{|c|}{ Code Description } & \multicolumn{1}{|c|}{$\begin{array}{c}\text { Number of } \\
\text { Recurrences }\end{array}$} & \multicolumn{1}{c|}{ Category } \\
\hline Enjoyment & 15 & Reception \\
\hline Learning awareness & 17 & Progress sensation \\
\hline Team work & 8 & \\
\hline Confidence & 10 & $\begin{array}{l}\text { Students' suggestions } \\
\text { for implementation }\end{array}$ \\
\hline $\begin{array}{l}\text { Feeling comfortable } \\
\text { with the activity }\end{array}$ & 15 & \\
\hline Desire of variety & 8 & \\
\hline Total & 73 & \\
\hline
\end{tabular}

\section{Discussion}

Crossing information from the three sources of data; video-recorded narratives, semistructured interviews, and artifacts, I came to the following conclusions to finally answer the research question.

First: How may a teacher use TRPGs as task-based activities in the English language classroom? Certainly, it is possible. According to my observation of the students' enjoyment, answers, and opinions about TRPG games, the procedures followed in this study to implement TRPGs as task-based activities can work. I recommend the following steps: First, organizing groups considering students' individualities; second, presenting examples of interaction in a fictional context by applying role-play as rehearsal tasks; third, explaining the games' fictional context and introducing students to the game mechanics. Fourth, performing examples of mechanics resolution and narrative interaction. Once the teacher has followed the beforementioned steps, it is necessary to present games sessions as series of activation tasks with clear objectives (Nunan, 2004).

Also, based on the observations and students' declarations, it is crucial to propose challenges that imply different solutions with degrees of uncertainty; for example: To search for a lost person in a forest, treat that person's wounds, cross a river and take the person to a town. The uncertainty of TRPG game sessions is what makes players improvise solutions and courses of action. Therefore, using visual and kinesthetic aids (teacher's body language, mimicry, use of images, sounds, and posters) are important to stimulate students' imagination and immersion in the experience. Hence, students can appeal to their different learning styles (Brown, 2007; Gilakjani, 2012). 
Nonetheless, TRPGs are storytelling activities that imply social interaction, and imagination; additionally, participants have to resolve tasks to progress in their own story with TRPGs. Therefore, their implementation demands constant teacher supervision to motivate and help students as well as to prevent disruptive behavior. Hence, the teacher must adopt an active monitorial role, becoming a temporary member of each of the students' groups, performing characters that give students interaction opportunities to use their emerging skills, and offering spontaneous advice and correction (Nunan, 2004; Scrivener, 2005 p. 94).

However, I saw something worth reflecting on and clarifying. The observations and video recordings showed more stimuli to learning styles and emerging skill activation during role-play activities than in TRPGs (see Table 3 above). That is not contradictory. TRPGs are role-play exercises with game mechanics. Hence, if role-plays affect aspects such as language skills activation and development of sociolinguistic and paralinguistic competencies, TRPGs can do it too.

On the other hand, it is necessary to mention that TRPGs are prone to disciplinary difficulties and do not work well with large groups. I see that this kind of activity works well with a maximum of 20 students divided into five groups. Furthermore, TRPGs as task-based activities demand from the teacher several skills like acting, mimicry, storytelling, and familiarity with pop culture elements that can be interesting in order for students to propose contexts and tasks interesting for them to see in a narrative experience (Mackay, 2001; Garcia, 2016).

Second: Did the application of TRPGs as task-based activities give evidence of the seventh-grade students' L2 speaking skill? Was there any sign of change in the students' performance? I observed that the students did reach/achieve progress in their L2 language performance between the first and fourth implementations. The samples from intervention one to four become progressively more complex. In intervention one, the students limited themselves to asking for permissions and help and expressing opinions as good, bad, delicious, etc. They sometimes made use of prefabricated structures for greetings, introductions, and functions to interact in restaurants, bus stops and hotels. In intervention two, the students tried to react to unscripted situations such as a sudden lack of money and necessity of 124 discounts. In interventions three and four, focused on fantasy TRPG (Crocco, 2016; Ferreira \& Carvalho, 2013; Garcia, 2016; Grouling, 2010; Reinhold, 2018), the students not only reacted, but manipulated the fictional situations in their favor by preparing ambushes for a fictional monster and planning how to rescue a fictional person. In that regard, they were more likely to be risk-takers, experimenting with language using different communication strategies (Richards \& Rodgers, 2001), activating emerging skills, and conveying meaning (Ellis, 2018; Nunan, 2004; Richards \& Rodgers, 2001). 
Third: What did the researcher notice about exploring an alternative to affect the foreign language classroom learning environment and motivation in the form of TRPG games? Social interaction in the frame of a collaborative game, in which there are no losers, helped increase the students' confidence and motivation (Ferreira \& Carvalho, 2013). Remarkably, the students highlighted that collaborative work was essential; teamwork made interconnected learning possible, boosting scaffolding processes among peers (Garcia, 2016). Moreover, this close interaction among classmates working for a common goal increased their shared necessity of using L2 (Vansteenkiste, Lens, \& Deci, 2010).

\section{Conclusion}

Finally, to give an answer to the research question, "How does the application of tabletop roleplaying games (TRPGs), used as a task-based activities, give evidence concerning the development of speaking English as a foreign language process?”, I observed elements that facilitated verbal communication in the EFL classroom, namely: learning awareness, collaborative work, written and oral language experimentation, and scaffolding processes.

In that order of ideas, the application of adapted TRPGs helped the participating students to produce language that was pragmatic and meaningful in a gamified classroom context. They were able to work with the resources at their disposal and that appealed to their different learning strategies (Brown, 2007; Richards \& Rodgers, 2001). These, in turn, positively affected other skills like writing and social interaction (Nunan, 2004).

Also, the implementation of TRPGs in the classroom presented a safe environment for the students to experiment with language, fostering social interaction, and experience interconnected learning among peers; all this raised their levels of confidence (Garcia, 2016). Positively, the implementation of those kinds of games helped deal with the following elements: motivation, methodology, and learning environment (Coşkun, 2016; Rivera, 2010; Vargas, 2015). Accordingly, the generation of ZPD in scaffolding processes was possible, emerging among peers and not only with a (professional) "expert" (Ortega, 2009 , p. 225). Besides, the sense of belonging to a group raised the identified necessity of using English as the L2 to enjoy the groups' participation in a game (Vansteenkiste, Lens, \& Deci, 2010).

However, TRPGs, although beneficial, can be demanding for teachers. Teachers should have competence in storytelling and knowledge of game mechanics. Teachers should also be knowledgeable in current pop culture movies and literature. All these activities require more work on the part of the teacher, and as collaborative activities, require constant monitoring. In that regard, these activities can present challenges to classroom management. 
Fabio Adrián Torres-Rodríguez,

Liliana Martínez-Granada

\section{References}

ALTE CEFR Special Interest Group (SIG). (2016, July 3rd). ALTE Association of language testers in Europe. ALTE Association of language testers in Europe: www.alte.org

Brown, H. D. (2007). Principles of language learning and teaching (5th ed.). Pearson Education, Inc.

Burns, A. (2009). Doing action research in English language teaching. Routledge, Taylor and Francis Group. https://doi.org/f74t

Cassie, J. (2016). Level up your classroom: The quest to gamify your lesson and engage your students. ASCD Learn, Teach, Lead.

Christiansen, T. (2015). The rise of English as the global lingua franca. Is the world heading towards greater monolingualism or new forms of plurilingualism? Lingue e Linguaggi 15(2015), 129-154. https://doi:10.1285/i22390359v15p129

Colegio Alkor. (2016, October 25). English at Colegio Alkor. www.englishinalkorschool.blogspot. com.co

Córdoba, E. (2016). Implementing task-based language teaching to integrate language skills in an EFL program at a Colombian university. Profile: Issues in Teachers' Professional Development, 18(2), 13-27. https://doi.org/g2xg

Coşkun, A. (2016). Causes of the 'I can understand English but I can't speak' Syndrome in Turkey. i-manager's Journal on English Language Teaching, 6(3), 1-12. https://doi.org/f74v

Crocco, F. (2016). The RPG Classroom; Reporpusing game mechanics for the gamification of education. In A. Byers \& F. Crocco, The role-playing society; Essays on the cultural influence of RPGs (pp. 278-294). McFarland \& Company. https://doi.org/f9cn

Dörnyei, Z. (1995). On the teachability of communication strategies. TESOL Quarterly, 29(1), 5585. https://doi.org/bpvwks

Ellis, R. (2018). Reflections on task-based language teaching. Multilingual Matters. https://doi.org/f8r2

Ferreira, M. A., \& Carvalho, H. F. (2013). Learning through role-playing games: An approach for active learning and teaching. Revista Brasileira de Educaşão Médica, 37(1), 80-88. https://doi. org/ggwwdh

Garcia, A. (2016). Teachers as Dungeon master; connected learning, democratic classrooms, and rolling for inititive. In A. Byers \& F. Crocco, The role-playing society (pp. 164-183). McFarland \& Company, Inc., Publishers. https://doi.org/f9cn

Gilakjani, A. P. (2012). Visual, auditory, kinaesthetic learning styles and their impacts on English language teaching. Macrothink institute: Journal of Studies in Education. 2(1), 104-113. https:// doi.org/f74w

Gower, R., Phillips, D., \& Walters, S. (2005). Teaching practice; A band book for teachers in training. Macmillan Education.

Grouling, J. (2010). The creation of narrative in tabletop roleplaying games. McFarland \& Company, Inc. 
Juneja, P. (2019, Abril 18). Oral communication. ManagementStudyGuide.com. https://www.managementstudyguide.com/oral-communication.htm

Mackay, D. (2001). The fantasy role-playing game: A new performing art. McFarland \& Company, Inc.

Mackey, A., \& Gass, S. M. (2005). Second language research; methodology and design. Lawrence Erlbaum Associates, Inc., Publishers.

Martin-Rubió, X. (2018). Contextualising English as a Lingua Franca: From data to insights. Cambridge Scholars Publishing.

Ministerio de Educación Nacional (2016). Pedagogical principles and guidelines; suggested English curriculum. Ministerio De Educacion Nacional de Colombia.

Monsalve, S., \& Correal, A. (2006). Children's oral communication in English class activities: An exploratory study. Profile: Issues in Teachers' Professional Development, 7, 131-146. https://bit. ly/3eq5VL1

Montoya, C., \& Uribe, D. (2016). Jugar para aprender no es aprender jugando: ludificación de procesos pedagógicos. Perspectiva Empresarial, 3(2), 15-25. https://doi.org/g2xj

Nunan, D. (1992). Research methods in language learning. Cambridge University Press.

Nunan, D. (2004). Task-Based language teaching. Cambridge University Press. https://doi.org/dvm$\mathrm{vgb}$

Ortega, L. (2009). Understanding second language acquisition. Hodder Education.

Perdomo, I., \& Rojas, A. (2019). La Ludificación Como Herramienta Pedagógica: Algunas Reflexiones Desde la Psicología. Revista de Estudios y Experiencias en Educación 18(36), 161-175. https://doi.org/g2xk

Poovey, C. C. (2014). Ted Gellar-Goad and the secret of the sphinx. Wake Forest Magazine 62(1), 19-27. https://bit.ly/3t1CKmJ

Reinhold, R. (2018). The postmodern joy of roleplaying games; agency, ritual and meaning in the medium. McFarland \& Company, Inc., Publishers.

Richards, J. C., \& Rodgers, T. S. (2001). Approaches and methods in language teaching ( $2^{\text {nd }}$ ed.). Cambridge University Press. https://doi.org/c6vtds

Rivera, J. D. (2010). Authentic oral interaction in the EFL class: What it means, what it does not. Profile: Issues in Teachers' Professional Development 12(1), 47-61. https://bit.ly/3dJNAcU

Rocha, F. Q. (2018). Roll a D6: A role-playing game based approach to the EFL classroom. Brazilian English Language Teaching Journal, 9(2), 535-546. https://doi.org/f74x

Rodríguez, J., \& Rodríguez, M. (2010). Task-based language learning: Old approach, new style. A new lesson to learn. Profile: Issues in Teachers' Professional Development 12(2), 165-178. http:/ / ref. scielo.org/z8jxzp

Scrivener, J. (2005). Learning teaching. Macmillan Education.

Swarthout, D. (2019, April 18). Oral communication: definition, types \& advantages. Study.com. https:// bit.ly/3eosSy3 
Fabio Adrián Torres-Rodríguez,

Liliana Martínez-Granada

Vaca, A. M., \& Gómez, L. F. (2017). Increasing EFL learners' oral production at a public school through project-based learning. Profile: Issues in Teachers' Professional Development, 19(2), 57-71. http://dx.doi.org/10.15446/profile.v19n2.59889

Vansteenkiste, M., Lens, W., \& Deci, E. L. (2010). Intrinsic versus extrinsic goal contents in selfdetermination theory: Another look at the quality of academic motivation. Educational Psychologist, 41(1), 19-31. https://doi.org/ccqkfv

Vargas, G. (2015). Three communication difficulties of EFL students. Revista de Lenguas Modernas, 23, 221-233. https://doi.org/f74z

Woods, T. (2016). Raiding the last frontier; Overcomming the language barrier in the ESL classroom. In A. B. Crocco, The role-playing society: Essays on the cultural influence of RPG (págs. 98 - 121). McFarland \& Company Inc., Publishers. https://doi.org/f9cn 